\title{
IMPLIKASI IUU FISHING DALAM PENGELOLAAN SUMBER DAYA IKAN DI INDONESIA
}

\author{
Subhat Nurhakim \\ Peneliti pada Pusat Riset Perikanan Tangkap, Ancol-Jakarta \\ Teregristrasi I tanggal: 31 Maret 2009; Diterima setelah perbaikan tanggal: 2 April 2009; \\ Disetujui terbit tanggal: 3 April 2009
}

\begin{abstract}
ABSTRAK
Pada tatanan dunia, regional, dan nasional, dewasa ini isu kegiatan yang berkaitan dengan IUU fishing adalah merupakan ancaman utama terhadap sediaan ikan. Telah banyak inisiatif international yang didukung oleh organisasi internasional seperti FAO telah menyiapkan International Plan of Action dari IUU Fishing. Walaupun jumlah negara yang mencoba mengembangkan National Plan of Action dari IUU Fishing terus bertambah, tetapi dalam beberapa hal, kegiatan IUU Fishing merupakan hal yang banyak terjadi dan merupakan ancaman nyata terhadap perikanan lokal. Adalah benar bahwa perhatian dunia terhadap IUU Fishing terus meningkat sebagai akibat yang nyata penurunan sediaan ikan dunia secara drastis. Perkiraan kasar secara keseluruhan menunjukkan bahwa paling tidak 30\% dari hasil tangkapan perikanan dunia diperoleh dari kegiatan IUU Fishing. Ini memperlihatkan bahwa masalah IUU Fishing tersebut meningkat dengan kuat, terutama bila dilihat dari percepatan penurunan ketersediaan sumber daya perikanan. Tulisan ini menyajikan halhal yang berkaitan dengan pengkajian sediaan dan pengelolaan perikanan seperti juga halnya kegiatan IUU Fishing yang terjadi di Indonesia. Dampak IUU Fishing terhadap hasil pengkajiaan sediaan pada akhirnya digunakan sebagai informasi dasar untuk pengelolaan perikanan juga dibahas. Rekomandasi disampaikan dalam kaitannya untuk mengurangi kegiatan IUU Fishing dan meningkatkan pengkajian sediaan ikan dan pengelolaan perikanan.
\end{abstract}

KATA KUNCI: IUU fishing, stock assessment, fisheries management, Indonesia

ABSTRACT: IUU fishing implication on fish resources management of Indonesia. By: Subhat Nurhakim

At global, regional, and national levels, issues associated with IUU fishing activities currently constitute a major world-wide threat to fisheries stocks. There have already been many international initiatives supported by international organizations such as the FAO which have been engaged in the International Plan of Action on IUU fishing. Although an increasing number of countries are trying to develop national plan of actions on IUU fishing, in many parts, IUU fishing practices are still common place and constitute a real threat to local fishers. Indeed, there is increasing global concern about IUU fishing practices due to the fact that global fish stocks are declining drastically. Approximate estimations suggest that overall at least 30\% of world-wide fisheries catch is obtained from IUU fishing activities. This shows that the problem is increasingly severe, especially in view of the accelerating overall decline in available fisheries resources. This paper presents briefly regarding stock assessment and fisheries management as well as IUU fishing activities that undertake in Indonesian waters. The impact of IUU fishing to the result of stock assessment, that finally used as

Korespondensi Penulis: 
basic information for fisheries management is also discuss. Recommendation is made in relation to eliminate IUU fishing activities and improvement of stock assessment and fisheries management.

\section{KEYWORDS: IUU fishing, stock assessment, fisheries management}

\section{PENDAHULUAN}

Luas lautan, panjang garis pantai serta banyaknya pulau di Indonesia, merupakan kendala tersendiri dalam pengelolaan sumber daya di mana di antaranya menyebabkan perolehan data perikanan yang baik menjadi sulit. Dalam hal memperoleh data perikanan di mana hasil tangkapan dapat didaratkan pada banyak pulau dan lokasi sepanjang pantai menyebabkan data hasil tangkapan maupun upaya penangkapan tidak dapat diperoleh secara langsung, akan tetapi melalui pendugaan yang seringkali hasilnya tidak akurat.

Keadaan ini diperburuk dengan maraknya kegiatan penangkapan ilegal (Illegal fishing) pada beberapa perairan di Indonesia (di antaranya Laut Arafura, Laut Sulawesi, dan Laut Cina Selatan) yang dapat memberikan akibat hilangnya data dan informasi penting (unreported catch) yang sangat diperlukan dalam pengkajian stock.

Perkembangan kegiatan penangkapan di Indonesia yang sangat beranekaragam baik yang bersifat komersial maupun subsisten, membutuhkan perangkat peraturan dan perundangan yang memadai di mana kenyataan menunjukan bahwa ada kegiatan perikanan yang belum diatur sebagaimana mestinya (unregulated fishing).

Seiring dengan pesatnya pembangunan dan perkembangan perikanan tangkap di Indonesia dewasa ini, tuntutan akan dilaksanakannya suatu pengelolaan perikanan semakin menjadi lebih terasa. Gejala kelebihan tangkap sudah terlihat pada beberapa Wilayah Pengelolaan Perikanan (WPP), bahkan beberapa group spesies di beberapa WPP telah memperlihatkan lebih tangkap, baik recruitment over fishing maupun growth over fishing, tanpa adanya suatu pengelolaan yang baik pada gilirannya sumber daya ikan akan mengalami kepunahan.

Pengelolaan sumber daya perikanan adalah suatu tindakan melalui pembuatan peraturan yang didasari oleh hasil kajian ilmiah yang kemudian dalam pelaksanaannya diikuti oleh kegiatan Monitoring, Controlling, dan Surveilance di mana tujuan akhirnya adalah suatu kelestarian sumber daya perikanan dan lingkungannya serta memberikan keuntungan secara ekonomi maupun biologi. Arti pengelolaan mencakup pengembangan dan pengendalian di mana acuan yang dianut dalam pelaksanaannya adalah konsep perikanan yang bertanggungjawab (responsible fisheries).

Langkah-langkah untuk dapat melaksanakan pengelolaan sumber daya perikanan yang sesuai dengan kaidahkaidah konsep perikanan yang bertanggungjawab seperti upaya meningkatkan kualitas data statistik perikanan serta mencegah dan menghilangkan kegiatan IUU Fishing telah dilaksanakan oleh Departemen Kelautan dan Perikanan.

Dalam kaitannya dengan pengelolaan perikanan, di samping kurang memadainya akurasi data perikanan yang akan sangat 
mempengaruhi hasil kajian ilmiah tentang sediaan ikan yang dihasilkan berdasarkan pada metode yang menggunakan masukan data hasil dan upaya penangkapan, kompleksitas perikanan daerah tropis yang multi species dan multi gears memberi peringatan kepada kita untuk lebih berhatihati dalam menggunakan model pengkajian sediaan yang pada umumnya berasal dari negara sub tropis yang sejatinya dirancang untuk diterapkan kepada sediaan single species.

Walaupun demikian, kekurangan data dan informasi serta kurang memadainya kajian ilmiah dengan metode yang bertumpu kepada data hasil dan upaya penangkapan ikan maupun belum tersedianya model-model pengkajian ikan untuk multi species, tidak dapat dijadikan alasan untuk tidak melakukan pengelolaan. Dengan mengacu kepada pengelolaan dengan prinsip pendekatan kehati-hatian (precautionary approach), pendugaan sediaan ikan melalui metode yang tidak memerlukan masukkan data hasil dan upaya penangkapan dipadukan dengan kajian ilmiah yang dilandasi oleh perilaku indikator biologi, populasi, dan eksploitasi, dapat dijadikan pilihan sebagai acuan tambahan dalam pengelolaan sumber daya ikan.

\section{KEGIATAN PENANGKAPAN ILEGAL, TIDAK DILAPORKAN DAN TIDAK DIATUR (IUU FISHING)}

Di tingkat Global, Regional, dan Nasional, permasalahan yang berkaitan dengan kegiatan penangkapan ikan ilegal, tidak dilaporkan dan tidak diatur (IUU fishing) sudah merupakan ancaman dunia terhadap kelestarian sediaan ikan yang ada saat ini. Seperti yang diidentifikasi oleh Sekretaris Jenderal Persatuan Bangsa Bangsa dalam laporannya kepada General Assembly pada tahun 1999 yaitu IUU
Fishing merupakan salah satu masalah besar saat ini yang mempengaruhi perikanan dunia (UNGA A/54/429, para. 249). IUU fishing secara perlahan akan merusak implementasi konservasi dan pengelolaan yang diatur oleh Negara dan Organisasi Pengelolaan Perikanan Regional (RFMO) serta akan memberikan dampak jangka panjang pada pengelolaan yang berkelanjutan dari sediaan ikan. Praktek penangkapan yang tidak berkelanjutan, kegiatan penangkapan ilegal oleh kapal asing pada perairan di bawah yuridiksi suatu Negara, kapasitas armada yang berlebihan, hasil tangkapan yang tidak dilaporkan atau dilaporkan secara tidak benar, kurang efektifnya pengendalian bendera dan pelabuhan negara (flag and port state control), dan open access regime pada perikanan laut lepas adalah merupakan perhatian dunia yang berkaitan dengan IUU Fishing.

Dalam membahas persoalalan IUU fishing, seringkali yang lebih diperhatikan adalah unsur penangkapan ikan ilegal (Ilegal fishing) dibandingkan dengan unsur penangkapan ikan yang tidak dilaporkan (Unreported fishing) dan penangkapan ikan yang tidak diatur (Unregulated fishing). Fenomena ini merupakan hal umum yang terjadi di berbagai negara dan apabila masalah ini dibiarkan terus, maka dikhawatirkan akan memberikan informasi yang keliru, terutama dalam hal pengelolaan sumber daya ikan. Seperti halnya dengan sektor lainnya yang mengandalkan bahan alami, maka sumber daya ikan yang ada sudah semakin berkurang ini akan mudah mengalami overfishing dan selanjutnya sediaan ikan tersebut akan mengalami salah kelola apabila data dan informasi yang tersedia tidak akurat.

Definisi dari masing-masing komponen IUU Fishing menurut paragrap 3 pada 
Rencana Aksi Internasional IUU Fishing (IPOA-IUU fishing) adalah:

1. Penangkapan ikan illegal (Illegal fishing) berhubungan dengan kegiatan:

a. Yang dilakukan oleh kapal nasional atau asing pada satu perairan di bawah yuridiksi suatu negara, tanpa izin negara yang bersangkutan, atau bertentangan dengan hukum dan aturan di negara tersebut.

b. Yang dilakukan oleh kapal berbendera negara yang tergabung dalam RFMO akan tetapi melaksanakan kegiatan yang bertentangan dengan aturan konservasi dan pengelolaan yang dianut oleh organisasi di mana negara tersebut menjadi anggota, atau ketetapan peraturan lain yang berkaitan dengan hukum internasional yang berlaku.

c. Pelanggaran terhadap hukum nasional dan kewajiban internasional, termasuk pelanggaran yang dilaksanakan oleh negara anggota terhadap RFMO terkait.

Penangkapan ikan illegal dapat terjadi dalam bermacam bentuk misalnya melakukan penangkapan tanpa izin atau secara tidak syah atau melakukan kegiatan penangkapan bertentangan dengan aturan penangkapan yang telah ditetapkan di mana kegiatan yang disebutkan terakhir termasuk di dalamnya penangkapan sampai melampaui batas yang telah ditetapkan, menangkap spesies ikan yang dilarang, atau melakukan penangkapan pada perairan yang terlarang untuk menangkap ikan.

Penangkapan ikan illegal berhubungan pula dengan kegiatan yang membuat aturan konservasi dan pengelolaan yang dibuat oleh negara atau RFMO terhadap suatu sediaan ikan di dalam wilayah hukumnya menjadi tidak berfungsi misalnya penggunaan metode penangkapan yang merusak seperti pemakaian racun dan bahan peledak, penggunaan mata jaring yang kecil, alat tangkap dengan teknik dan cara penangkapan yang sangat merusak (penggunaan perangkap, menutup perairan, dan merusak karang) serta penangkapan juvenile dan ikan yang muda.

Walaupun tidak mudah untuk mengidentifikasi dan menduga tingkat penangkapan ikan illegal di Indonesia, kegiatan ini terutama terjadi pada Zona Ekonomi Eksklusif (Cacaud, 2001) dan dilakukan paling banyak oleh kapal-kapal asing (Purwaka \& Sibuea, 1993).

Pada umumnya, ada dua macam penangkapan ikan illegal oleh kapal asing. Yang pertama adalah pelanggaran daerah penangkapan yaitu lebih banyak dilakukan di dekat pantai yang sebenarnya dipersiapkan untuk nelayan tradisional daripada di perairan Zona Ekonomi Eksklusif seperti yang telah ditetapkan dalam persyaratan kapal asing melakukan penangkapan (McDorman, 1992, Damanhuri, 2001). Yang kedua adalah penangkapan ikan illegal oleh kapal ikan asing pada perairan pantai dalam hal mana tidak ada kesepakatan bilateral tentang fishing acces. (McDorman, 1992).

Penangkapan ikan illegal di perairan Indonesia dilakukan juga oleh kapal ikan domestik dengan cara melakukan penangkapan tanpa mempunyai izin penangkapan atau melanggar syarat-syarat yang tertera dalam surat izin penangkapan. Ada beberapa bentuk ketidaktaatan terhadap persyaratan yang tertera dalam surat izin penangkapan di antaranya penggunaan alat atau cara yang dilarang oleh peraturan/hukum yang ada misalnya penggunaan alat tangkap atau ukuran mata jaring yang tidak diperbolehkan, atau 
menggunakan metode penangkapan yang merusak seperti dinamit dan racun (Sastrowiryono, 2000). Walaupun penggunaan cara penangkapan tersebut dilarang secara hukum, penggunaan cara penangkapan tersebut banyak digunakan oleh nelayan hampir di seluruh perairan Indonesia (Cacaud, 2001). Hal lain yang perlu menjadi perhatian dalam hal penangkapan ikan illegal oleh kapal domestik adalah pemalsuan keterangan yang berhubungan dengan bobot kapal, dimensi, pemilik asal, dan nama yang tercatat.

2. Penangkapan ikan yang tidak dilaporkan (Unreported fishing) berhubungan dengan kegiatan:

a. Tidak melaporkan hasil tangkapan atau melaporkan secara tidak benar kepada lembaga nasional yang berwenang dan bertentangan dengan hukum dan peraturan nasional; atau

b. Melakukan penangkapan di perairan yang menjadi kewenangan suatu RFMO, akan tetapi tidak melaporkan atau melaporkan secara tidak benar dan bertentangan dengan prosedur pelaporan organisasi tersebut.

Berkenaan dengan Unreported fishing, kegiatan ini dapat dilakukan oleh kapal penangkap ikan yang berizin maupun yang tidak berizin. Dengan atau tanpa maksud memberikan laporan penangkapan yang benar kepada yang berwenang, hasil tangkapan yang diperoleh dilaporkan secara tidak benar atau dilaporkan lebih sedikit dari yang sesungguhnya termasuk di dalamnya hasil tangkapan yang dibuang (discard).

Penangkapan ikan yang tidak dilaporkan merupakan permasalahan yang nyata di Indonesia. Data perikanan dari perairan Indonesia dilaporkan dan dicatat secara tidak benar (Monintja, 1996) yang pada gilirannya nanti menghasilkan data dan informasi yang tidak dapat dipercaya, atas dasar data itu kemudian kebijakan dibuat (Kusumastanto, 2003). Ada dua jenis kegiatan penangkapan ikan yang tidak dilaporkan dilakukan oleh kapal ikan Indonesia dan asing. Yang pertama adalah kesalahan fihak nelayan komersial dalam hal pelaporan ikan hasil tangkapan di tempat pelelangan ikan yang telah ditetapkan. Sering terjadi ikan hasil tangkapan dijual langsung kepada tempat proccesing atau diekspor tanpa menggunakan dokumen yang syah (Nurhakim \& Tsamenyi, 2001). Jenis yang kedua adalah melakukan transhipment di tengah laut dan melakukan ekspor secara tidak syah. Dalam banyak hal, kapal ikan asing tidak melaporkan hasil tangkapannya di pelabuhan perikanan yang ditunjuk. Kapal ikan asing yang mempunyai izin resmi tidak jarang melakukan transhipment secara tidak syah di tengah laut. Kegiatan penangkapan ikan yang tidak dilaporkan mengakibatkan rendahnya kualitas data untuk mendukung kebijakan pengelolaan yang dibuat oleh Direktorat Jenderal Perikanan Tangkap (Nurhakim \& Tsamenyi, 2001).

3. Penangkapan ikan yang tidak diatur (Unregulated Fishing) berhubungan dengan kegiatan:

a. Penangkapan ikan dilakukan di wilayah pengelolaan RFMO tertentu oleh kapal tanpa kebangsaan atau oleh kapal berbendera Negara bukan anggota RFMO yang bersangkutan atau oleh kelompok perikanan (fishing entity) dalam hal kegiatan yang tidak mengikuti aturan dan bertentangan dengan aturan konservasi dan pengelolaan organisasi tersebut; atau

b. Penangkapan ikan dilakukan di wilayah pengelolaan RFMO tertentu atau terhadap sediaan ikan tertentu di mana tidak ada penerapan aturan konservasi dan pengelolaan maupun 
aturan pelaksanaan kegiatan penangkapan yang sesuai dengan tanggung jawab Negara dalam hal konservasi sumber daya hayati laut di bawah hukum internasional.

Penangkapan yang tidak diatur, berdasarkan pada Rencana Aksi Internasional-IUU (IPOA-IUU) tidak hanya kegiatan perikanan yang berhubungan dengan tidak adanya pedoman pengelolaan untuk suatu wilayah perairan atau sediaan ikan, akan tetapi berarti pula walaupun terdapat pedoman pengelolaan, kegiatan penangkapan ikan yang tidak dikendalikan dan tidak diatur tetap berlansung (Edeson, 2000). Dari ketiga komponen IUU Fishing, hanya penangkapan yang tidak diatur yang dapat atau tidak dapat dikatakan tidak syah, tergantung dari keadaan dan lingkungan.

Seorang nelayan melaksanakan kegiatan penangkapan yang tidak diatur karena negara atau kelompok negara yang bersangkutan belum menetapkan aturan pengelolaannya, untuk kegiatan perikanan tersebut tidak dapat diartikan sebagai sesuatu kegiatan yang dibenarkan di dalam aturan diluar hukum.

Sebagai contoh di Indonesia, kegiatan penangkapan yang tidak diatur dapat terjadi dalam bentuk kurang memadainya peraturan untuk perikanan subsisten, tidak adanya perundangan yang mengatur pelaporan data dan tidak adanya aturan terhadap spesies tertentu terutama jenisjenis ikan hias.

Diperkirakan 30\% dari total produksi hasil tangkapan ikan dunia diperoleh melalui kegiatan IUU Fishing (FAO Report, 2004). Hal ini menunjukkan bahwa persoalan ini sudah semakin serius, apalagi mengingat sumber daya ikan yang tersedia semakin menurun.

\section{Penyebab IUU Fishing di Indonesia}

Dari sudut pemanfaat sumber daya ikan, beberapa faktor yang berpotensi menjadi penyebab IUU fishing di antaranya 1) menipisnya sediaan sumber daya di suatu perairan tertentu yang mengakibatkan perairan yang subur menjadi tujuan tempat penangkapan walaupun tidak sesuai dengan izin yang diberikan atau tanpa izin sama sekali, 2) ada pendapat bahwa sumber daya ikan tidak dapat punah, 3) kurangnya pemahaman para pemanfaat sumber daya ikan terhadap penggunaan alat dan cara penangkapan yang merusak lingkungan, 4) keinginan untuk memperoleh keuntungan secara jangka pendek tanpa memikirkan keberlanjutan daripada keberadaan sumber daya ikan tersebut, serta 5) belum ada kesadaran tentang pentingnya data dan informasi untuk pengelolaan sumber daya.

Keadaan tersebut di atas diperburuk oleh faktor lain yang dianggap memberikan sumbangan kepada kegagalan sistem pengelolaan perikanan yang ditenggarai dapat meningkatkan terjadinya IUU Fishing. Faktor-faktor tersebut termasuk belum adanya batas maritim yang disetujui dengan negara tetangga, luasnya perairan laut Indonesia, kurang cukupnya tenaga penegak hukum yang terlatih, dan lemahnya kerangka kerja perundangan, administrasi, dan penegakan hukum yang memadai.

Beberapa batas maritim Indonesia dengan Negara tetangga belum ditetapkan dengan jelas seperti batas dengan Thailand, Filipina, Timor Leste, dan Papua New Guinea. Tidak adanya batas maritim yang disetujui antar negara negara tersebut menyebabkan terjadinya kegiatan penangkapan secara illegal oleh kapal asing di perairan Indonesia yang tumpang-tindih dengan wilayah hukum negara lain. Sebagai contoh dalam hal ini adalah Laut Sulawesi di mana ada batas maritim yang menjadi 
sengketa antara Indonesia dan Filipina menjadi penyebab utama IUU Fishing di daerah tersebut.

Faktor kedua yang memberi sumbangan terhadap terjadinya IUU Fishing adalah wilayah hukum perairan laut Indonesia yang luas, merupakan tantangan tersendiri dalam penegakan hukum perikanan (Tsamenyi, 2002). Sebagai negara kepulauan, Indonesia tidak hanya terletak antara benua Asia dan Australia, akan tetapi juga terletak di antara Samudra Hindia dan Samudra Pasifik (Kusumaatmadja, 1996). Posisi geografis antara dua Samudra yang penting di dunia ini, menyebabkan Indonesia terbuka terhadap laut lepas yang merangsang banyaknya kegiatan IUU Fishing, baik yang dilakukan oleh kapal asing maupun kapal berbendera Indonesia sendiri. Dengan demikian posisi geografis Indonesia dapat dianggap sebagai asset dalam hal kekayaan biodiversity laut, sekaligus tanggung jawab dalam hal penegakan hukum perikanan (COREMAP, Puslitbang Oseanology-LIPI, 1998).

Faktor ketiga adalah terbatasnya jumlah staff penegak hukum terlatih yang mempunyai kemampuan dalam mengendalikan kegiatan IUU Fishing (Tsamenyi, 2002). Indonesia hanya mempunyai 534 observer perikanan dan 458 penyidik perikanan di bawah Departemen Kelautan dan Perikanan. Permasalahan di atas diperburuk oleh kurangnya sarana penegakan hukum seperti kapal patroli dan pesawat terbang. Angkatan Laut RI hanya mempunyai 114 kapal perang dan 63 pesawat terbang di mana secara teknologi kapal tersebut dalam kondisi yang kurang baik (Sastrowirjono, 2000). Keadaan tersebut mempersulit lembaga penegak hukum untuk menangkap kapal kapal yang melakukan kegiatan IUU fishing (Sondakh, 2003).
Faktor keempat yang menyumbang berkembangnya IUU fishing di Indonesia adalah kurang memadainya penegakan hukum dan peraturan perikanan (Tsamenyi, 2002). Masalah ini disebabkan oleh adanya celah dalam aturan dan perundangundangan pengelolaan perikanan yang ada sekarang. Belum adanya aturan yang berkaitan dengan pelarangan kapal berbendera Indonesia melakukan penangkapan di perairan negara lain merupakan faktor yang nyata dalam menunjang terjadinya IUU Fishing. Keprihatinan juga tercermin dengan tidak adanya aturan dan perundangan dalam pendaftaran dan pemberian izin kapal di laut bebas.

\section{Telaah Kasus IUU Fishing di Indonesia}

Telaah yang berkaitan dengan IUU Fishing dalam artian menduga besaran hasil tangkapan yang disebabkan karena penangkapan illegal (illegal fishing), hasil tangkapan yang tidak tercatat (unreported) maupun hasil tangkapan yang dihasilkan oleh perikanan yang belum diatur (unregulated fishing) belum banyak dilakukan, sehingga jumlah keseluruhan ikan yang sesungguhnya diambil dari laut (total extraction) belum diketahui dengan benar.

Suatu kajian kualitatif yang berkaitan dengan IUU Fishing telah dilakukan di perairan Laut Cina Selatan dan Laut Sulawesi. Adapun dugaan kuantitatif dilakukan dengan mempergunakan suatu metode yang tidak baku sehingga hasil yang diperoleh belum akurat.

Kegiatan penangkapan ikan illegal dan tidak dilaporkan di perairan Laut Cina Selatan dilakukan oleh kapal ikan asing maupun Indonesia, terutama oleh nelayan lokal dari Provinsi Kalimantan Barat. 
Ditenggarai bahwa trawl domestik dengan ukuran 70 GT diperkirakan tidak melaporkan hasil tangkapannya kepada lembaga perikanan yang berwenang sekitar 1.200-2.400 ton ikan per tahun. Kapal ikan asing yang pada umumnya berbendera Thailand diperkirakan tidak melaporkan ikan dan udang hasil tangkapannya sekitar 200350 ton per tahun (Widodo \& Susanto, 2003).

Dari hasil pengamatan diperoleh informasi bahwa terdapat penangkapan ikan yang tidak diatur dalam hal penggunaan lampu dengan kekuatan 12-20 kWh pada pengoperasian alat tangkap pukat cincin yang dapat meningkat suhu air dan tertangkapnya ikan yang muda (Widodo \& Susanto, 2003).

Kegiatan penangkapan illegal dan tidak dilaporkan di periaran Zona Ekonomi Eksklusif Laut Sulawesi terutama dilakukan oleh kapal ikan Filipina di mana sebagian besar ikan hasil tangkapan tidak tercatat, dan diperkirakan sekitar 70\% hasil tangkapan tuna oleh kapal ikan Filipina dari perairan Zona Ekonomi Eksklusif Indonesia didaratkan di Filipina tanpa melapor terlebih dahulu kepada pelabuhan yang telah ditunjuk (Gafa, et.al, 1999).

Kegiatan penangkapan ikan illegal lainnya yang dilakukan di Laut Sulawesi adalah penggunaan cara penangkapan yang memberikan dampak merusak sumber daya secara jangka panjang seperti penggunaan mata jaring yang kecil dan rumpon, penangkapan ikan dengan menggunakan dinamit dan sianida juga dilakukan oleh kapal kapal ikan berizin maupun tidak (Tsamenyi, 2002).

Suatu kerja sama riset antara Pusat Riset Perikanan Tangkap-Badan Riset Kelautan dan Perikanan dengan University of British Columbia (UBC)-Canada dengan dukungan dana dari FAO tentang IUU
Fishing di Laut Arafura telah dilaksanakan pada tahun 2007 (Wagey et al., 2009). Secara umum, hasil yang diperoleh adalah pada periode 1996-2000, rata rata tahunan nilai (median) hasil tangkapan I/legal, Misreported, dan Discard dari gabungan ketiga alat tangkap adalah secara berturut turut 833.254, 464.633, dan 259.594 ton yang kemudian pada 2001-2005 menjadi $663.626,373.827$, dan 240.639 ton, atau secara total hasil tangkapan ikan IUU dari 1.652.401 ton pada periode 1996-2000 menjadi 1.494.809 ton pada 2001-2005.

\section{PENGKAJIAN SEDIAAN IKAN (FISH STOCK ASSESSMENT) DALAM PENGELOLAAN PERIKANAN}

Dalam konteks pengelolaan perikanan, adalah mustahil tidak membicarakan pengkajian sediaan ikan (fish stock assessment). Pengelolaan perikanan dan pengkajian sediaan ikan merupakan dua sisi mata uang yang tidak dapat dipisahkan. Ini berarti bahwa untuk berhasilnya suatu pengelolaan sangat diperlukan hasil pengkajian sediaan yang didukung oleh data dan informasi yang benar, dipihak lain, data dengan presisi yang tinggi akan dihasilkan bila pengelolaan sumber daya tersebut dilaksanakan dengan baik dalam artian berbagai peraturan pengelolaan perikanan yang memadai tersedia dan telah diimplentasikan dengan baik atau dengan kata lain kegiatan IUU fishing tidak terjadi.

Sering sekali istilah pengkajian sediaan ikan diartikan sebagai sinonim dengan saran biologi tentang berbagai tingkat eksploitasi. Dalam pandangan seperti ini, maka tugas para ahli biologi pengkajian sediaan cukup sekedar mengkaji status dan potensi produksi dari sediaan dan membuat sejumlah rekomendasi tentang hasil tangkapan yang diperbolehkan dan upaya penangkapan optimum. 
Pada hakekatnya pengkajian sediaan ikan tidak sekedar melakukan interpretasi dari statistik atas hasil tangkapan (catch) komersial untuk mengestimasi potensi menghasilkan dari sumber daya ikan (potential yield). Arti suatu pengkajian sediaan yang dilakukan secara baik, jauh lebih lengkap dari pengertian tersebut diatas.

1. Pengkajian sediaan meliputi pemahaman tentang dinamika dari perikanan. Dengan demikian, pengkajian sediaan dilakukan atas dasar pengertian bahwa perikanan merupakan sejumlah sediaan dinamis yang dari waktu ke waktu akan merespon terhadap sejumlah peraturan pengelolaan dan berbagai faktor ekstrinsik.

2. Pengkajian sediaan mencakup pembuatan sejumlah prediksi tentang berbagai kecenderungan (trends) yang mungkin terjadi sebagai respon terhadap perubahan kebijaksanaan dari waktu ke waktu.

3. Pengkajian sediaan dapat merumuskan kebijaksanaan yang dapat digunakan untuk mengatasi berbagai perubahan yang tidak dapat diprediksi sebelumnya dan yang kejadiannya tidak dapat dihindarkan.

Model-model pengkajian sediaan dapat dibagi dua kelompok besar, yaitu yang termasuk ke dalam kelompok model-model holistik dan kelompok model-model analitik.

Program pengkajian sediaan yang simultan dilaksanakan pada seluruh wilayah pengelolaan perikanan Indonesia dimulai pada tahun 1991, kemudian pada tahun 1997 dan 2002. Sampai tahun 1997, pengkajian sediaan sepenuhnya bertumpu pada data dan informasi yang berasal dari buku statistik perikanan dan data hasil kapal penelitian di mana hasil yang diperoleh adalah nilai MSY, kemudian dibandingkan dengan hasil tangkapan saat terakhir untuk memperoleh status tingkat pengusahaan untuk setiap group spesies pada setiap wilayah pengelolaan perikanan.

Walaupun hasil kajian sediaan ikan tersebut kemudian dipakai sebagai acuan administrator dalam menentukan langkah kebijakan, terutama alokasi upaya pada suatu perairan tertentu, akan tetapi keabsahan dari hasil kajian tersebut selalu dipertanyakan dan menjadi bahan perdebatan.

Sejatinya data statistik perikanan yang ada sekarang ini pada awalnya dirancang bukan untuk keperluan pengkajian sediaan (stock assessment) tetapi untuk pencatatan produksi yang didaratkan sehingga yang dicatat bukan keterangan dari mana ikan ditangkap, akan tetapi di mana ikan didaratkan. Diperburuk dengan maraknya IUU fishing, maka sejak 2002, pengkajian kegiatan mencoba lebih menekankan data dan informasi hasil riset berupa trend dari indikator biologi, populasi, lingkungan, maupun perikanan.

\section{PENGELOLAAN SUMBER DAYA IKAN LAUT DI INDONESIA}

Sumber daya ikan merupakan salah satu sumber daya alam yang mampu pulih namun bukan tidak terbatas. Mereka dapat mengalami penipisan kelimpahan (abundance), bahkan kemusnahan (collapse) jika dibiarkan dalam keadaan nirkelola. Penyusunan berbagai alternatif/opsi pengelolaan memerlukan sejumlah masukkan data dan informasi terutama yang berkaitan dengan perilaku sumber daya ikan dalam merespon berbagai langkah pengelolaan yang diterapkan.

Dalam kebijakan pengelolaan perikanan tangkap dikenal input control, dan output control yang kemudian di dalam pelaksanaannya nanti masing-masing 
dapat dikobinasikan dengan ecological control di mana Indonesia dalam hal ini telah menerapkan kebijakan input control yang dikombinasikan dengan ecological control.

Beberapa kebijakan pengelolaan perikanan tangkap yang dilaksanakan di Indonesia dan dapat dikelompokan sebagai input control adalah kebijakan tentang potensi dan alokasi sumber daya ikan pada setiap wilayah pengelolaan perikanan, dan jumlah, jenis serta ukuran alat tangkap. Sedangkan kebijakan yang mengarah kepada ecological control di antaranya adalah tentang penetapan ukuran mata jaring untuk alat tangkap tertentu, ukuran minimal ikan yang boleh ditangkap, larangan penangkapan daerah tertentu, larangan pengunaan alat tangkap dan bahan tertentu untuk penangkapan, dan larangan memperdagangkan jenis ikan tertentu.

Untuk memperoleh jumlah upaya optimum (maksimum upaya yang diperbolehkan) untuk suatu kelompok jenis ikan pada suatu perairan tertentu diperoleh melaui metoda surplus produksi di mana parameter input adalah serial data hasil tangkapan dan upaya dari statistik perikanan. Cara lain yang ditempuh untuk menetapkan Upaya optimum adalah dengan menduga potensi lestari lebih dulu melalui survei eksplorasi kemudian dibagi dengan hasil tangkapan per unit upaya alat penangkapan standar.

Dalam proses pemanfaatan sumber daya ikan tersebut, pemantauan, pengendalian, dan pengawasan diterapkan untuk mengamankan sumber daya yang dimanfaatkan dari kegiatan eksploitasi (upaya) yang dilakukan.

Jumlah upaya di dalam pemanfaatan sumber daya tertentu dikendalikan (control) melalui perizinan dan seperangkat peraturan tentang cara melakukan eksploitasi sumber daya ikan secara benar dan bertanggungjawab untuk menghindari terlampauinya upaya optimum dan kerusakkan sumber daya yang dimanfaatkan. Hubungannya dengan pengendalian, pembuatan keputusan, alokasi sumber daya ikan dilaksanakan oleh Direktorat Jenderal Perikanan Tangkap. Sistim perizinan yang berlaku di Indonesia saat ini adalah izin dikeluarkan oleh pusat (Departemen Kelautan dan Perikanan) untuk kapal berukuran diatas 30 GT, oleh Pemerintah Daerah tingkat propinsi untuk kapal berukuran antara 10-30 GT dan oleh Pemerintah Daerah tingkat Kabupaten untuk kapal berukuran antara 5-10 GT, sedangkan kapal/perahu di bawah 5 GT tidak perlu izin, hanya perlu terdaftar.

Kegiatan pengawasan (surveillance) dan penegakan hukum diselenggarakan untuk memelihara ketaatan para pemanfaat sumber daya terhadap aturan pengendalian yang diterapkan untuk kegiatan penangkapan. Fungsi pengawasan (surveillance) seperti penegakan hukum dari peraturan perundang-undangan yang diberlakukan merupakan tugas dan fungsi Direktorat Jenderal Pengawasan dan Perlindungan Sumber Daya Kelautan dan Perikanan. Peningkatan kegiatan pengawasan perikanan yang dilaksanakan oleh Departemen Kelautan dan Perikanan adalah merupakan hasil dari peningkatan kapasitas pengawasan perikanan, yang dilakukan melalui 1) peningkatan jumlah dan kapasitas operasi kapal pengawas perikanan Departemen Kelautan dan Perikanan, dan 2) peningkatan ketrampilan dan pengetahuan pengawas perikanan, baik dari pelatihan maupun operasi bersama dengan TNI-AL dan POLRI. Dalam kurun waktu lima tahun Departemen Kelautan dan Perikanan telah mengadakan dan mengoperasikan 16 kapal untuk pengawasan perikanan di laut dan 11 speedboat untuk pengawasan perikanan di 
perairan pantai. Dalam kurun waktu 4 tahun proporsi kapal yang bermasalah mengalami penurunan dari 26\% (2003) menjadi $12 \%$ (2006).

Untuk mengetahui pengaruh upaya penangkapan terhadap sumber daya, maka dilakukan suatu pemantauan (monitoring) yang terus-menerus melalui pengumpulan data dan informasi serta analisis untuk mengukur perkembangan karakter upaya dan jumlah sumber daya yang dieksploitasi, dalam hal ini dilaksanakan oleh Direktorat Jenderal Perikanan Tangkap. Dalam hal pemantauan data perikanan, upaya perbaikan telah dilaksanakan dalam hal cara pengumpulan data, jenis-jenis data dan informasi yang dikumpulkan serta pelatihan untuk meningkatkan kemampuan para pelaksana baik pelaksana lapangan maupun data analis. Pertemuan tahunan dilakukan untuk tingkat provinsi oleh Direktorat Sumber Daya Ikan untuk melakukan validasi terhadap data dan informasi yang diperoleh. Tercermin dari penampilan data dan informasi pada buku statistik nasional perikanan perikanan tangkap, alat tangkap dan hasil penangkapan (misalnya pukat ikan) yang tahun sebelumnya tidak pernah tercatat, sejak tahun 2004 sudah dapat dilihat. Demikian pula group spesies ikan ekonomis penting (misalnya tuna) yang sebelumnya digabung menjadi satu kelompok hasil tangkapan, sejak tahun 2004 telah dipecah menjadi hasil tangkapan per spesies.

Di samping hal yang disebutkan di atas, ada aspek lain yang amat terkait dengan pengolalaan perikanan yaitu aspek konservasi yang merupakan tugas dan fungsi dari Direktorat Jenderal Kelautan, Pesisir, dan Pulau-Pulau Kecil.

\section{IMPLIKASI IUU FISHING DALAM PENGELOLAAN SUMBER DAYA IKAN DI INDONESIA}

Secara umum IUU Fishing dapat memberikan dampak negatif terhadap keberlangsungan usaha perikanan yaitu 1) kurangnya kebijakan pengelolaan, 2) hilangnya keuntungan dari perikanan, dan 3) lebih tangkap sediaan ikan yang mengakibatkan keuntungan yang rendah, punahnya populasi ikan yang dapat membuat kegagalan usaha perikanan komersial, hilangnya spesies ikan dan ancaman terhadap keamanan pangan.

Kenyataan bahwa kegiatan IUU Fishing sampai saat ini terjadi di perairan territorial dan Zona Ekonomi Eksklusif Indonesia, baik oleh nelayan asing maupun nelayan domestik secara jelas akan memberikan dampak buruk terhadap mekanisme pengelolaan sumber daya ikan.

Seperti telah disampaikan terdahulu bahwa data dan informasi yang mempunyai presisi yang tinggi dihasilkan bila pengelolaan perikanan tangkap terselenggara dengan baik. Suatu upaya yang simultan dalam hal meningkatkan kualitas hasil pengkajian sediaan dan menciptakan sistem pengelolaan perikanan tangkap yang baik perlu segera dilaksanakan.

Sebelum tahun 2002 berdasarkan pada survei eksplorasi di perairan Laut Arafura diperoleh hasil dugaan potensi ikan demersal 202.340 ton, potensi tersebut dibandingkan dengan total hasil tangkapan ikan demersal 156.800 ton, berdasarkan pada statistik perikanan pada tahun terahir. Sandingan kedua angka tersebut 
menunjukan bahwa sumber daya demersal di Laut Arafura dalam tahapan under exploited.

Suatu kajian ulang tentang potensi telah dilakukan untuk ikan demersal di perairan Laut Arafura dengan memperhitungkan dugaan jumlah hasil dan upaya penangkapan yang diakibatkan dari kegiatan IUU Fishing, hasil tangkapan lestari (MSY) yang diperoleh adalah rata rata 1.350.000 ton/tahun dengan nilai bawah 1.151.825 ton/tahun dan nilai atas 1.634.375 ton/tahun. Adapun upaya optimum (Optimum effort) diperoleh nilai rata rata 931 kapal standar dengan nilai bawah 794 kapal standar dan nilai atas 1126 kapal standar (Badrudin, pers com 2007).

Upaya nyata yang memanfaatkan sumber daya demersal di Laut Arafura saat ini ternyata telah melewati upaya optimum nya sehingga penambahan upaya tidak memberikan kenaikan terhadap hasil penangkapan, atau dengan kata lain keadaan perikanan demersal di LautArafura telah mengalami tangkap lebih.

Hasil ini bersesuaian dengan hasil penelitian terhadap indikator perikanan dan biologi ikan demersal maupun indikator lingkungan di LautArafura yang menunjukan bahwa tekanan penangkapan terhadap sumber daya ikan demersal sudah lebih tangkap yaitu:

1. Terdapat perubahan komposisi ukuran dan jenis komunitas sumber daya udang dan ikan demersal, di mana ukuran ikan maupun udang semakin kecil, ikan yang berukuran besar semakin langka tertangkap mengindikasikan food web bertambah pendek.

2. Indikasi dari sisi operasional penangkapan terlihat bahwa untuk hasil tangkapan yang sama upaya penangkapan meningkat, alokasi armada penangkap mengarah ke daerah pemusatan schooling, dan pemanfaatan sumber daya hampir di semua jalur dan lokasi penangkapan. Peningkatan besar armada penangkapan diikuti oleh trend penurunan produtivitas dari tahun ke tahun.

3. Secara ekologis, bahkan terdapat lingkungan perairan yang tidak layak untuk kehidupan biota laut, akibat besar hasil tangkapan sampingan yang dibuang kembali ke laut. Terjadi perubahan komunitas mikrobentos yang merupakan salah satu mata-rantai atau simpul food chain dan food web.

Kedua contoh perhitungan diatas memperingatkan kepada kita betapa pentingnya kualitas dan kelengkapan data dalam pengkajian sediaan, pertimbangan berdasarkan pada faktor lain perlu diperhatikan untuk memperoleh suatu gambar keadaan sediaan yang lebih utuh untuk menentukan langkah kebijakan yang benar.

Ditinjau dari sudut ketersediaan data dimana IUU fishing merupakan masalah dalam perikanan tangkap di Indonesia, bila pengkajian sediaan diartikan hanya sebagai kegiatan melakukan interpretasi dari statistik atas hasil tangkapan (catch) komersial untuk mengestimasi potensi menghasilkan dari sumber daya ikan (potential yield), maka keluaran dari suatu pengkajian sediaan akan memberikan gambaran yang salah tentang suatu sediaan.

Untuk memperoleh keluaran yang sesuai dengan arti kajian sediaan yang sebenarnya, suatu penerapan kajian sediaan dalam artian yang utuh tidak sekedar menganalisis data hasil tangkapan dan upaya dari data statistik atau hasil riset dari kapal survei akan tetapi juga mengikut 
sertakan telaah yang berkaitan dengan daur hidup, dinamika populasi, dan identifikasi sediaan, serta lingkungan perairan.

Pendekatan lain melalui konsep Use of Indicator for Sustainable Development \& Management perlu mulai dikembangkan, misalnya melalui pemantauan terhadap kecenderungan perubahan indikator indikator populasi/biologi ikan, lingkungan, kapal, dan kapasitas penangkapan serta sosial ekonomi. Hal ini perlu mengingat bahwa saat ini kebijakan pengelolaan perikanan pada sebagian besar Negara di Asia Tenggara telah dikembangkan berdasarkan pada konsep dan metodologi dari perikanan negara sub tropis sehingga tidak dapat diaplikasikan dengan sempurna baik dalam pelaksanaannya maupun secara scientifik pada perikanan di perairan tropis.

Di dalam pengendalian (control) pelaksanaannya kebijakan pengelolaan tidak dapat hanya bertumpu pada penetapan dan pengendalian jumlah kapal (input control), akan tetapi pengendalian lain melalui aturan aturan yang bernafaskan pendekatan ekologi (ecological control) berdasarkan pada pemantauan indikator sumber daya, lingkungan, dan sosial ekonomi, lebih ditingkatkan lagi, misalnya pengaturan alat tangkap yang ramah lingkungan (termasuk rancang bangun alat tangkap/alat bantunya, dan cara serta strategi penangkapan), penetapan persyaratan waktu dan tempat pelaksanaan penangkapan ikan boleh dilaksanakan, serta penetapan jenis dan ukuran ikan yang boleh ditangkap.

Dalam kaitannya dengan sistem perizinan penangkapan sebagai fungsi kendali (input control), satuan upaya sebaiknya lebih diperhatian, kemampuan penangkapan (fishing ability) seperti cara dan strategi penangkapan, kebenaran tetang bobot kapal (sering terjadi mark down) diketahui dengan benar oleh si pemberi izin, jumlah kapal yang sama akan memberikan kemampuan menangkap yang berbeda terhadap sumber daya target. Hal lain yang perlu diperhatikan adalah pembagian kewenangan dalam hal pemberian izin (oleh pusat, propinsi, dan kabupaten), di mana saat ini menghasilkan ekses yang kurang menguntungkan dalam pengelolaan perikanan tangkap, dalam artian bila tidak ada koordinasi yang baik tentang jumlah upaya yang diberikan, izin yang dikeluarkan dapat melebihi daya dukung sumber daya itu sendiri. Pendaftaran ulang kapal penangkap untuk seluruh ukuran kapal selain dilaksanakan di tingkat pusat juga perlu dilaksanakan di tingkat Kabupaten dan tingkat propinsi, untuk memperoleh suatu acuan tentang berapa jumlah upaya yang sebenarnya sudah ada pada suatu perairan.

Tekanan penangkapan illegal oleh kapal asing serta komitmen terhadap konvensi internasional cenderung mendorong pengawasan lebih ditujukan kepada kapal penangkap ikan asing dan kapal domestik skala industri. Sistim pengawasan berbasis masyarakat perlu lebih ditingkatkan lagi mengingat kegiatan IUU fishing yang dilakukan nelayan domestik dari skala subsisten sampai sedang nampaknya memberikan kontribusi yang cukup nyata dalam menurunnya kualitas sumber daya ikan di Indonesia. Mengingatnya luasnya perairan Indonesia, pengawasan tidak dapat seluruhnya dipikul oleh pusat, akan tetapi dukungan nyata dari pemerintah daerah maupun kota adalah sangat diperlukan.

Sampai saat ini kebijakan pengelolaan perikanan tangkap melalui pengendalian keluaran (output control) nampaknya belum dapat dilaksanakan, keadaan perikanan tropis yang terdiri atas berbagai macam jenis ikan serta alat tangkap yang sulit dipantau serta kenyataan hasil tangkapan 
yang tidak dilaporkan masih tinggi merupakan kendala utama dalam pelaksanaan kebijakan pengelolaan melalui pengendalian keluaran.

Sudah banyak hal diungkapkan di atas tentang opsi kebijakan dalam pengelolaan perikanan maupun pengkajian sediaan kaitannya dengan kenyataan bahwa kegiatan IUU Fishing merupakan masalah yang sedang dihadapi di Indonesia. Yang jadi pertanyaan adalah bagaimana caranya merakit opsi opsi tersebut sehingga dapat menjadi suatu kebijakan pengelolaan yang utuh sehingga tujuan pengelolaan yang diinginkan dapat tercapai.

Pengeloaan perikanan membutuhkan suatu rencana pengelolaan perikanan yang baik dan khususnya rencana tersebut didukung oleh para pemangku kepentingan yang berkepentingan di bidang perikanan. Dengan terlibatnya para pemangku kepentingan dalam perencanaan akan meningkatan rasa memiliki dan rasa tanggung jawab terhadap pengelolaan.

\section{KESIMPULAN DAN REKOMENDASI}

Penangkapan ikan secara ilegal, hasil tangkapan yang tidak dilaporkan serta kegiatan penangkapan yang tidak diatur (IUU fishing) baik yang dilakukan oleh kapal asing maupun kapal berbendera Indonesia telah terjadi hampir di seluruh perairan Indonesia, baik di perairan teritorial maupun Zona Ekonomi Eksklusif Indonesia.

Kebijakan pengelolaan perikanan tangkap di Indonesia cenderung hanya melalui pengendalian upaya yang memanfaatkan sumber daya tertentu (input kontrol) di mana selama kegiatan IUU fishing berlangsung, nampaknya hasil penentuan upaya optimum (optimum effort) yang mendekati kebenaran tidak mudah dicapai. Selanjutnya pengendalian upaya dilaksanakan melalui mekanisme perizinan di mana sistem kewenangan perizinan tersebar di pusat, propinsi dan kabupaten. Hal ini akan memberi peluang kepada setiap pemegang kewenangan untuk mengeluarkan izin tanpa memperhatikan daya dukung sumber daya yang dimanfaatkan. Hal ini dapat memberikan peluang pula akan terjadinya IUU fishing dan tambahan beban tersendiri di dalam pengawasan dan pemantauannya.

Dalam kondisi IUU Fishing berlangsung di mana presisi data dan informasi rendah, pemantauan terhadap kecenderungan perubahan indikator indikator populasi/ biologi ikan, lingkungan, kapal dan kapasitas penangkapan, serta sosial ekonomi untuk pembangunan dan pengelolaan perikanan tangkap yang berkelanjutan perlu dilaksanakan sebagai pertimbangan lain di dalam menentukan langkah kebijakan pengelolaan perikanan tangkap selain angka potensi.

Sediaan ikan di beberapa perairan laut Indonesia yang menunjukkan kecenderungan menurun atau sudah mengalami tangkap lebih ditenggarai bahwa kegiatan IUU fishing merupakan penyebab utamanya yang dapat diselamatkan dengan suatu sistem pengelolaan yang memadai. Sistem pengelolaan yang selama ini dilakukan perlu diperbaiki, dalam artian pemerintah maupun para pemangku kepentingan lainnya mempunyai persepsi yang sama terhadap arti dan tujuan pengelolaan serta bersama-sama melaksanakannya secara konsisten. Berbagai hal yang perlu menjadi pertimbangan dan mendapat perhatian sebagai berikut:

1. Sosialisasi tentang kegiatan IUU fishing, terutama kepada para pemangku kepentingan, peranannya dalam mendorong keterpurukan dan 
Implikasi IUU Fishing dalam Pengelolaan Sumber Daya Ikan di Indonesia (Nurhakim, S.)

hambatannya terhadap program pembangunan perikanan yang berkelanjutan.

2. Meningkatkan kemampuan riset pengkajian sediaan (stock assessment) dalam arti yang utuh, terutama pengembangan model untuk perikanan tropis.

3. Meningkatkan pelaksanakan pemantauan (monitoring) dan evaluasi (termasuk perbaikan statistik perikanan) terhadap seluruh kegiatan eksploitasi dan pembangunan perikanan dengan melibatkan para pemangku kepentingan.

4. Unsur pengendalian (control) yang meliputi sistem perizinan dan peraturan perlu ditinjau kembali untuk disempurnakan sesuai dengan kaidah pengelolaan yang bertanggungjawab.

5. Sadar akan luas dan belum memadai sepenuhnya prasarana dan sarana pengawasan (surveilance), mekanisme kerja antar unsur pengawas serta pemanfaat sumber daya perlu ditingkatkan.

6. Meningkatkan kapasitas dan kapabilitas di bidang perikanan tangkap baik dari sisi kelembagaan maupun sumber daya manusia yang meliputi tenaga peneliti, administrator, dan pemanfaat sumber daya.

7. Meningkatan peran aktif Indonesia di dalam Organisasi Pengelolaan Perikanan Regional.

8. Dengan suatu persepsi yang sama, rencana pengelolaan perikanan perlu mendapat dukungan penuh baik dari pemerintah maupun dari para pemanfaat sumber daya.

\section{DAFTAR PUSTAKA}

Cacaud, P. 2001. Indonesia Review of Legal Issues and Revised Draft Fisheries Law. Food and Agriculture Organization of the United Nations, Rome.
COREMAP. 1999. Peraturan dan Perundangan yang Berkaitan dengan Perikanan Karang. COREMAP Sekretariat. 34 pp.

Damanhuri, D. S. 2001. Kapal Ikan Asing. Koran Replubika. 16 Oktober, 2001. Jakarta.

Doulman, D. J. 2000. Illegal, unreported, and unregulated fishing: Mandate for an International Plan of Action. Document AUS:IUU/2000/4. FAO. 2004. New tools in the IUU battle. http://www.fao.org/ newsroom/en/focus/ 2004/47127/ article_47142en.html.

Edeson, W. 2000. Tools to address IUU Fishing: The Current Legal Situation. Experts Consultation on Illegal, Unreported, and Unregulated Fishing Organised by the Government of Australia in Cooperation with FAO. Sydney, Australia, 15-19 May 2000. AUS:IUU/2000/8. 2000. 13 pp.

Gafa, B., I G. M. Sedana \& K. Susanto. 2001. Management Plan Tuna dan Cakalang di perairan Laut Sulawesi dan sekitarnya. Laporan teknis proyek.

Kusumaatmadja, M. 1996. Pembangunan yang Berkelanjutan dan Kelestarian Laut: Tantangan dari UNCLOS dan Agenda 21. Pusat Archipelago, Hukum dan Studi Pembangunan. Bandung, Indonesia. 1996.

Kusumastanto, T. 2003. Kebijakan Laut Maritim Negara Berkembang di Era Otonomi Daerah. PT. Gramedia Pustaka Utama. Jakarta. Indonesia. 2003.

Mc Dorman, T. L. 1992. Foreign Fishing and Compliance with Coastal State Laws, in Kathleen I. Matics \& Ted L. McDorman 
(eds). SEAPOL International Workshop on Challenges to Fishery Policy and Diplomacy in South-East Asia, Rayong Thailand, 6-9 December 1992, SouthEast Asian Programme in Ocean Law, Policy and Management.

Monintja, D. R. 1996. Pemanfaatan Zona Ekonomi Eksklusif Indonesia dan permasalahannya. Makalah disampaikan pada Pertemuan Lanjutan International Hukum Laut. Fakultas Hukum. Universitas Padjadjaran. Bandung Indonesia. 19-31 Agustus.

Nurhakim, S. \& M. Tsamenyi. 2001. A Policy Management Framework to Combat IUU Fishing Activities, Australia, and Indonesia, Twenty Years of Collaborative Fisheries Research, Australian Centre for International Agricultural Research of the Australian Government and Dep. of Marine Affairs and Fisheries of the Republic of Indonesia.

Purwaka, T. H. \& B. Sibuea. 1993. Access to Indonesia 200 Miles EEZ, in Proceeding ICLOS Seminar on the Law of the Sea in the 1990's Offshore Resources Development. Bandung Indonesia, 24-26 January 1991. Law Consortium. Department of Education and Culture of the Republic of Indonesia and Nederlandse Raad Voor Jurisdische Samenwerking Met Indonesia.

Sastrowirjono, I. A. 2000. Seminar and Lokakarya Tentang Negara Maritim di Era Otonomi Daerah. Ikatan Jurnalis Indonesia, Jawa Timur, Surabaya, Indonesia. 14 November 2000.

Sondakh, B. K. (Staf Utama Angkatan Laut Indonesia). Penegakan Hukum dan Keamanan di Laut. Makalah disajikan pada Pertemuan Teknis Penegakan
Hukum Laut. Direktorat Jenderal Pengawasan Sumber Daya Kelautan dan Perikanan. Dep. Kelautan dan Perikanan RI. Jakarta. 11 Juni 2003.

Tsamenyi, M. 2002. Management and Policy Frameworks for Illegal, Unreported, and Undocumented Fishing in Indonesian and Philippines Waters. Project Proforma ACIAR: FIS/2002/19. $38 \mathrm{pp}$.

Undang Undang Republik Indonesia No.31/ 2004 tentang Perikanan.

United Nations Convention on the Law of the Sea. Montego Bay, Jamaica, 10 December 1982.

United Nations General Assembly. 1999. Fifty-fourth Session. Agenda Items 40 (a) and (c), Oceans the Law of the Sea; Law of the Sea; Results of the Review by the Commission on Sustainable Development of the Sectoral Theme of Oceans and Seas. Oceans and the Law of the Sea. Report of the SecretaryGeneral. A/54/429. 30 Sept.1999. 96 pp.

Wagey G. A., S. Nurhakim, V. P. H. Nikijuluw, Badrudin, \& T. J. Pitcher. 2009. A Study of Illegal, Unreported and Unregulated Fishing in the Arafura Sea, Indonesia. In press.

Widodo, A. A. \& K. Susanto. 2003. Indikasi IUU Fishing di Laut Cina Selatan (Studi Kasus di Wilayah Kalimantan Barat dan Kepulauan Riau). Pusat Riset Perikanan Tangkap. Dep. Kelautan dan Perikanan RI.

Widodo, J. 2002. Pengantar Pengkajian Stok Ikan. Pusat Riset Perikanan Tangkap. Badan Riset Kelautan dan Perikanan. Dep. Kelautan dan Perikanan. Jakarta. 16 pp. 